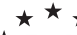

$\star$ Polityki Europejskie,

$\star$ Finanse i Marketing

$\star \star \star \quad 19(68) 2018$

Grzegorz Paluszak

Uniwersytet Warszawski

Joanna Wiśniewska-Paluszak

Uniwersytet Przyrodniczy w Poznaniu

\title{
Hipoteza efektywnego rynku versus analiza techniczna rynku finansowego
}

\section{THE EFFICIENT MARKET HYPOTHESIS VERSUS TECHNICAL ANALYSIS OF FINANCIAL MARKET}

Celem artykułu jest porównanie założeń hipotezy efektywnego rynku z efektami analizy technicznej. Problemem badawczym pracy jest: czy hipoteza efektywnego rynku $i$ analiza techniczna majq sprzeczny charakter czy wzajemnie się uzupetniaja? Hipoteza efektywnego rynku opiera sie na racjonalności inwestora, a analiza techniczna uwzględnia racjonalność $i$ nieracjonalność inwestora. Dlatego, $w$ artykule przedstawiono pojęcie analizy technicznej $i$ jej założenia. $W$ następnej części pracy przedstawiono metodę badań $i$ przedstawiono hipoteze efektywnego rynku finansowego $w$ kontekście założen $i$ wyników badań z analizy technicznej, porównują je ze sobq. Potem zaprezentowano zakres wykorzystywania analizy technicznej i jej ocene przez uczestników rynku finansowego. Na końcu przedstawiono wnioski z przeprowadzonych badań.

Słowa kluczowe: hipoteza efektywnego rynku, analiza techniczna, rynek finansowy, rynek akcji, racjonalność

\section{Wstęp}

Dokonując przedstawienia pojęcia analizy technicznej, warto przytoczyć pewne przesłanie „opinie są wartościowe, ale fakty tworzą ceny"1. Nawiązuje ono do przedmiotu analizy technicznej. Pojęcie analizy technicznej można sprowadzić do badania zmian cen $\mathrm{z}$ przeszłości $\mathrm{w}$ celu prognozowania jej zmian w przyszłości ${ }^{2}$. Analizę techniczną rozumie się też, jako proces oceny kształtowania się cen papierów wartościowych z przeszłości dla określenia jej prawdopodobnych cen w przyszłości ${ }^{3}$.

Ujmując, nieco szerzej analiza techniczna opiera się na prognozie przyszłej tendencji na rynku finansowym, na podstawie jej zachowania $\mathrm{z}$ przeszłości, a nie na podstawie danych fundamentalnych ${ }^{4}$. Analizę techniczną uważa się, również za dobrze

${ }^{1}$ A.Sopoćko: Giełda papierów wartościowych, PWE, Warszawa 1991, s. 152.

${ }^{2}$ P.Zielonka: Technical analysis as the representation of typical cognitive biases, International Review of Financial Analysis, vol. 13, nr 2, Summer 2004, s. 217.

${ }^{3}$ W.Tarczyński: Rynki kapitałowe. Metody ilościowe, vol. 1, Agencja Wydawnicza PLACET, Warszawa 1997, s. 33.

${ }^{4}$ R. Vigfusson: Switching Between Chartists and Fundamentalists: A Markov Regime-Switching Approach, International Journal of Finance and Economics, vol. 2, nr 4, 1997, s. 291-292. 
uzasadnioną metodę prognozowania przyszłych zmian na rynku przez generowanie sygnałów kupna lub sprzedaży opartych na specyficznych informacjach uzyskiwanych z cen, z przeszłości, oraz na psychologii rynku ${ }^{5}$. Stąd analizę techniczną traktuje się, jako badanie zachowań na rynku finansowym. Jego celem jest prognozowanie trendów cenowych w przyszłości ${ }^{6}$.

Analiza techniczna zasadza się na trzech podstawowych założeniach. Po pierwsze, rynek dyskontuje wszystko. Po drugie, ceny podlegają trendom. Po trzecie, historia powtarza się.

Z pierwszego założenia wynika, że badanie kształtowania się cen jest podejściem w pełni samowystarczalnym, skoro wszystkie czynniki wpływające na cenę rynkową papieru wartościowego znajdują w niej swoje odbicie. W drugim założeniu przyjmuje się, że celem badania wykresów cen jest rozpoznanie trendów w ich wczesnych fazach, aby dokonać transakcji giełdowej, zgodnie z kierunkiem tych trendów. Wczesne rozpoznanie panujących trendów na rynku umożliwia osiagganie ponadprzeciętnych zysków. Ponadto, ujawnia się w nim również irracjonalność zachowań inwestorów na rynku. Dzięki, irracjonalnemu zachowaniu przynajmniej części inwestorów jest możliwe osiagganie takich zysków. Trzecie założenie przedstawia się również, jako tezę, że kluczem do zrozumienia kształtowania się cen papierów wartościowych w przyszłości jest badanie ich zachowania $\mathrm{w}$ przeszłości, uwidaczniając jednocześnie dominująca na rynku psychologię hossy lub bessy. Jak można dostrzec, analiza techniczna w znacznym stopniu wiąże się z badaniem ludzkiej psychiki. Ludzka psychika reaguje, bowiem tak samo na podobne zmiany ${ }^{7}$.

Analiza techniczna jest procesem badania kształtowania się cen papieru wartościowego w przyszłości na podstawie zachowania jego ceny w przeszłości. Z tego pojęcia wynika, że przyszłość można prognozować na podstawie przeszłości. Wynikają $\mathrm{z}$ niego też jej założenia. Właśnie one stały się zaczynem do przeprowadzonych badań. W następnej części pracy przedstawiono metodę badań i przedstawiono hipotezę efektywnego rynku finansowego $\mathrm{w}$ kontekście założeń $\mathrm{i}$ wyników badań $\mathrm{z}$ analizy technicznej, porównując je ze sobą. Potem zaprezentowano zakres wykorzystywania analizy technicznej $\mathrm{i}$ jej ocenę przez uczestników rynku finansowego. Na końcu przedstawiono wnioski z przeprowadzonych badań.

\section{Cel i metoda badań}

Celem artykułu jest porównanie założeń hipotezy efektywnego rynku z efektami analizy technicznej. W artykule wykorzystano następujące metody badań: studia literaturowe, analizę opisową i analizę porównawczą. Analizie poddano literaturę polską i zagraniczną. Literatura zagraniczna pochodzi $\mathrm{z}$ uznanych czasopism finansowych,

\footnotetext{
${ }^{5}$ Ch.-W. Chen., Ch.-S. Huang, H.-W. Lai: The impact of date snooping on the testing of technical analysis: An empirical study of Asian stock markets, Journal of Asian Economics, vol. 20, nr 5, September 2009, s. 580.

${ }^{6}$ T. Nawrocki, B.Jabłoński: Inwestowanie na rynku akcji: jako ocenić potencjał rozwojowy spółek notowanych na GPW w Warszawie, Wydawnictwo CeDeWu, Warszawa 2011, s. 5.

7 J.J.Murphy: Analiza techniczna rynków finansowych, Wydawnictwo Finansowe WIG-Press, Warszawa 1999, s. 2-4; S.B. Achelis: Analiza techniczna od A do Z, Oficyna Wydawnicza LT\&P, Warszawa 1998, s. 2; R. Jóźwicki: Strategie Inwestycyjne, Wydawnictwo CeDeWu, Warszawa 2010, s. 2-4; J. Fang, Y. Qin, B. Jacobsen: Technical market indicators: An overview, Journal of Behavioral and Experimental Finance, vol. 4, 2014, s. 25-56.
} 
szczególnie publikowanych w ostatnich latach. Dotyczy ona hipotezy efektywnego rynku finansowego, a zarazem analizy technicznej na rynku finansowym. Przedstawiono założenia hipotezy efektywnego rynku finansowego i analizy technicznej oraz porównano jej założenia $\mathrm{z}$ wynikami badań.

\section{Hipoteza efektywnego rynku finansowego w kontekście analizy technicznej}

Hipoteza efektywnego rynku zdominowała badania finansów, przede wszystkim dzięki pracy E.F. Famy i M.E. Blume ${ }^{8}$. Bardzo duża część literatury przedmioty z lat 1970-tych dostarczyła dowodów dla słabej wersji tej hipotezy. Zgodnie z nią, zmiany cen akcji z przeszłości nie można wykorzystywać do prognozowania przyszłych dochodów z akcji. Jednakże, większość badań z analizy technicznej, w których pewne wzorce kształtowania się cen wynikają z informacji zawartych w cenach z przeszłości, mogą właśnie być wykorzystywane do predykcji przyszłych zmian cen. Zatem, wyniki analizy technicznej są sprzeczne ze słabą wersją hipotezy efektywnego rynku?

W tym miejscu już wypada uwypuklić, że możliwość osiągania zysków na podstawie analizy technicznej stanowi już dowód na nieefektywność rynku finansowego. Bowiem, gdyby rynki były efektywne, dyskontując wszystkie informacje dotyczące aktywów finansowych, wtedy nie można by generować znacznych zysków $z$ dotychczasowych zmian cen tych aktywów ${ }^{10}$.

Warto przypomnieć, na efektywnym rynku wszyscy uczestnicy zachowują się w sposób racjonalny, gdyż maksymalizują oczekiwaną użyteczność, a dodatkowo oni są zdolni właściwie przetwarzać wszystkie otrzymywane informacje ${ }^{11}$. Rynek jest efektywny, gdy wszystkie nowe informacje są na nim szybko i właściwie zinterpretowane przez jego uczestników oraz natychmiast brane pod uwage w cenach papierów wartościowych. Efektywny rynek musi spełniać pięć założeń. Po pierwsze, na takim rynku funkcjonuje wielu uczestników niezależnie od siebie. Po drugie, inwestorzy podejmuja decyzje racjonalnie, dlatego dokonują jednakowo wyceny papierów wartościowych. Po trzecie, uczestnicy rynku inwestują na takie same okresy. Po czwarte, nowe informacje napływają w sposób losowy, będąc niezależne od siebie. Po piąte, uczestnikom rynku nowo napływające informacje przekazuje się w tym samym czasie, a oni natychmiast wykorzystuja je w swoich decyzjach inwestycyjnych na giełdzie ${ }^{12}$. Jak można zauważyć, założenia hipotezy efektywnego rynku nie są zawsze zgodne $\mathrm{z}$ rzeczywistością funkcjonowania giełdy, a niektóre z nich są nawet nierealne. I tak, $\mathrm{np}$. G. C. Friesen, P. A. Weller, L. M. Dunham uważaja, że rynki reagują podobnie na wyraźnie publiczne jak i prywatne informacje, podkreślając jednocześnie, że wiele

${ }^{8}$ E.F.Fama, M.E.Blume: Efficient capital markets: A review of the theory and empirical work, Journal of Finance, vol. 25, 1970, s. 383-417.

${ }^{9}$ Ch.-W. Chen., Ch.-S. Huang, H.-W. Lai: The impact...op.cit, s.581.

${ }^{10}$ M.P.Taylor: Editor's Introduction, International Journal of Finance and Economics, vol. 2, nr 4, 1997, s. 264

11 P. Zielonka: Czym są finanse behawioralne, czyli krótkie wprowadzenie do psychologii rynków finansowych, Materiały i Studia, z. 158, NBP, Warszawa 2003, s. 6.

${ }^{12}$ D.Kacprzak: Czy ruchami cen na rynkach kapitałowych rządzi wyłącznie przypadek?, w: Rynek kapitałowy. Skuteczne inwestowanie, cz. 2, pod red. nauk. W.Tarczyński, Wydawnictwo Naukowe Uniwersytetu Szczecińskiego, Szczecin 2002, s. 233-234. 
modeli behawioralnych wymaga od inwestorów reagowania odmiennie na różnorodne typy informacji ${ }^{13}$.

Jak trudne do spełnienia są założenia efektywnego rynku ukazuje najnowsze badanie, które nie potwierdza hipotezy efektywności rynków akcji na świecie. Warto dodać, że w badaniu uwzględniono 1.336 spółek z różnorodnych rynków akcji w okresie od 1 stycznia 2001 r. do 31 grudnia 2012 r. $^{14}$.

B.R. Marshall, M.R. Young, L.C. Rose akcentują, że analitycy techniczni są zdania, że dane dotyczące cen akcji z przeszłości i danych związanych z ich obrotem, takich, jak wolumen, zawierają ważne informacje o zmianach nastawienia inwestorów i że reakcja na nowe informacje jest stopniowym procesem, który pozwala rozwijać się trendom. Pomimo szeroko rozpowszechnionej akceptacji tego twierdzenia i jego wykorzystywania przez praktykujących analizę techniczną pozostaje ono w sprzeczności z hipotezą efektywnego rynku ${ }^{15}$. Ponadto, P.Kuang, M.Schröder, Q.Wang przypominają, że po dekadach debaty, opłacalność inwestycyjnych reguł analizy technicznej pozostaje nadal nierozstrzygnięta. Bowiem, w warunkach hipotezy słabej wersji rynku efektywnego, racjonalni inwestorzy powinni szybko dokonywać arbitrażu, czerpiąc korzyści a reguły analizy technicznej mogą stać się, wtedy bezużyteczne ${ }^{16}$.

Jak można dostrzec, analiza techniczna, w której wykorzystuje się zmiany cen z przeszłości w celu predykcji zmian przyszłych cen jest diametralnie przeciwstawna do hipotezy rynku efektywnego. W teorii, analiza techniczna nie posiada żadnej użyteczności, gdy ceny kształtują się zgodnie już z hipotezą efektywności rynku. Przegląd literatury dokonany przez autorów potwierdza niejednoznaczność użyteczności w wykorzystywaniu analizy technicznej w prognozowaniu cen na rynku akcji ${ }^{17}$.

Może wynikać to, z trudności wykorzystywania analizy technicznej do poszczególnych akcji, a zarazem różnorodności jej wskaźników. Nie wszystkie z nich są efektywne dla każdej akcji. Wybór odpowiedniej metody analizy technicznej dla danej akcji jest, zatem trudny dla przeciętnych inwestorów ${ }^{18}$. Dodatkowym utrudnieniem jest fakt, rosnącej złożoności i zmatematyzowania tworzonych modeli, które stają się coraz mniej zrozumiałe dla inwestorów. W tej sytuacji, do skuteczności wyników uzyskanych

\footnotetext{
${ }^{13}$ G.C. Friesen, Paul A. Weller, Lee M.Dunham: Price trends and patterns in technical analysis: A theoretical and empirical examination, Journal of Banking and Finance, vol. 33, nr 6, 2009, s. 1089-1100.

${ }^{14}$ Anghel G.D.I.: Stock market efficiency and the MACD. Evidence from countries around the world, Procedia Economics and Finance, vol. 32, 2015, s. 1414-1431.

${ }^{15}$ B.R.Marshall, M.R. Young, L.C. Rose: Candlestick technical trading strategies: Can they create value for investors? Journal of Banking and Finance, vol. 30, nr 8, August 2006, s. 2303-2304.

${ }^{16}$ P.Kuang, M.Schröder, Q.Wang: Illusory profitability of technical analysis in emerging foreign exchange markets, International Journal of Forecasting, vol. 30, nr 2, 2014, s. 192.

${ }^{17}$ B.R.Marshall, R.H.Cahan: Is technical analysis profitable on a stock market which has characteristics that suggest it may be inefficient?, Research in International Business and Finance, vol. 19, nr 3, September 2005, s. 384-385.

${ }^{18}$ X.Lin, Z.Yang, Y.Song: Intelligent stock trading system based on improved technical analysis and Echo State Network, Expert Systems with Applications, vol. 38, nr 9, 2011, s. 11347.
} 
za pomocą metod analizy technicznej, wywodzących się $\mathrm{z}$ teorii chaosu ${ }^{19}$ i sieci neuronowych ${ }^{20}$, wypada podchodzić ze szczególną ostrożnością ${ }^{21}$.

Warto dodać, że psychologia ukazująca zakręty i zwroty zachowań ludzkich nie jest również zgodna $\mathrm{z}$ hipotezą efektywnego rynku. Zgodnie $\mathrm{z}$ nią, efektywny rynek funkcjonuje, dzięki inwestorom, którzy korzystając $z$ pełnej informacji, natychmiast po jej pozyskaniu, ustalają racjonalnie ceny ${ }^{22}$. Jednakże, w tym miejscu powstaje niejako retoryczne pytanie: czy w sprawach finansowych ludzie zawsze postępują racjonalnie? Niewiele jest, bowiem obszarów życia ludzi tak nasyconych emocjami i nieracjonalnością, jak stosunek ludzi do pieniędzy ${ }^{23}$. Dodatkowo, trudność w kierowaniu się hipotezą efektywnego rynku w dokonywaniu inwestycji na giełdzie i trzymania się założenia racjonalności inwestorów giełdowych ukazuje problem odmiennego odczytywania tych samych neutralnych informacji przez nich w dwóch skrajnych sytuacjach na giełdzie. W okresie ,paniki”, neutralną informację odczytuje się zazwyczaj negatywnie, a w czasie ,gorączki złota” interpretuje się ją pozytywnie ${ }^{24}$.

W tym miejscu należy podkreślić, że jak stwierdza M. Dusza, giełda składa się w $90 \%$ z psychologii w okresie krótkoterminowym i średnioterminowym ${ }^{25}$. Można sądzić, że perspektywy rozwoju analizy technicznej mogą wynikać, także z trudności hipotezy efektywnego rynku w wyjaśnianiu anomalii na giełdzie. W opinii M. Tabęckiej, anomalie giełdowe dowodzą, że inwestorzy okazują się coraz mniej racjonalni w podejmowaniu decyzji ${ }^{26}$. Wykorzystywanie anomalii giełdowych wymaga, bowiem skutecznego inwestowania, któremu może przeszkadzać nasza ludzka natura. Może ona prowadzić do wpadania przez ludzi w pułapki utrudniające im skuteczne inwestowanie takie, jak np. stosowanie uproszczeń, efekt zakotwiczenia, heurystyka dostępności czy też nadmierny optymizm ${ }^{27}$. Na podstawie literatury przedmiotu można stwierdzić, że skutecznemu inwestowaniu przeszkadzają również psychologiczne uwarunkowania percepcji rzeczywistości i podejmowania inwestycji na giełdzie (budowanie przekonań, preferencje i stany emocjonalne), wpływ otoczenia i interakcje międzyludzkie, społeczno-etyczne przesłanki wyboru inwestycji, zachowania zbiorowe, inklinacje inwestorów, ograniczenia arbitrażu czy też anomalie na giełdzie ${ }^{28}$ oraz przykładowe

${ }^{19}$ D. Kacprzak: Czy ruchami...op.cit.233-243; M. Krawczak M., A.Jakubowski, P.Konieczny, R.Kulikowski, A.Miklewski, G.Szkatuła: Aktywne zarządzanie inwestycjami finansowymi. Zagadnienia wybrane, Akademicka Oficyna Wydawnicza EXIT, Warszawa 2003, s. 393-395.

${ }^{20}$ W.Tarczyński: Wykorzystanie sztucznych sieci neuronowych na rynku kapitałowym, w: Rynek kapitałowy. Skuteczne inwestowanie, cz. 1, pod red. nauk. W.Tarczyński, Wydawnictwo Naukowe Uniwersytetu Szczecińskiego, Szczecin 2002, s. 133-146.

${ }^{21}$ P.L.Bernstein, A.Damodaran: Zarządzanie inwestycjami, Wydawnictwo K.E.Liber, Warszawa 1999, s. 225.

${ }^{22}$ I.Piekunko: Zjawiska „gorączki złota” i „paniki” na Giełdzie Papierów Wartościowych w Warszawie, w: Rynek kapitałowy. Skuteczne inwestowanie, cz. 2, pod red. nauk. W.Tarczyński, Wydawnictwo Naukowe Uniwersytetu Szczecińskiego, Szczecin 2002, s. 443 i 450.

${ }^{23}$ R.G. Hagstrom: Portfel Warrena Buffetta, Wydawnictwo Naukowo-Techniczne, Warszawa 2011, s. 115

${ }^{24}$ I.Piekunko: Zjawiska...op.cit., s.450.

${ }^{25}$ M.Dusza: Rynek kapitałowy w Polsce. Narodziny, pierwsze dziesięciolecie, perspektywy, Biblioteka Menadżera i Bankowca, Warszawa 1999, s. 17.

${ }^{26}$ M.Tabęcka: Nowoczesne i behawioralne podejście do teorii finansów oraz budowy portfela, w: Strategia zarządzania portfelem inwestycyjnym, pod red. nauk. J. Kotyński, LAM-Wydawnictwo AKADEMII FINANSÓW, Warszawa 2010, s. 49

${ }^{27}$ G.Spólnik: Efekt stycznia czyli o rynkowych anomaliach, Miesięcznik Kapitałowy, styczeń 2010, s. 40-41.

${ }^{28}$ A.Szyszka: Finanse behawioralne. Nowe podejście do inwestowania na rynku kapitałowym, Wydawnictwo Uniwersytetu Ekonomicznego w Poznaniu, Poznań 2009. 
założenia: wszyscy ludzie postępują racjonalnie i dążą tylko do tego, aby stać się bogatymi oraz wszyscy inwestorzy są tacy $\mathrm{sami}^{29}$, także błędy w oczekiwaniach czy preferencje jednostki a jej cechy psychologiczne ${ }^{30}$. Stąd podejmując się inwestowania na giełdzie trzeba przeanalizować swoje motywy, a przede wszystkim dopasować grę na giełdzie do własnej osobowości ${ }^{31}$.

\section{Zakres wykorzystywania analizy technicznej i jej ocena przez uczestników rynku finansowego}

Analizę techniczną wykorzystuje się we wszystkich okresach badawczych na różnorodnych segmentach rynku finansowego. I tak, np. R.Curcio, Ch.Goodhart, D.Guillaume, R.Payne badają opłacalność dziennych transakcji na rynku finansowym. Wykorzystując analizę techniczną $\mathrm{w}$ tym celu, dochodzą oni do wniosku, że pewne korzyści można czerpać w pewnych okresach trendów, choć nie zawsze ${ }^{32}$. Natomiast, G.S. Atsalakis, K.P. Valavanis korzystają $\mathrm{z}$ analizy technicznej dla prognozowanie zwrotów z akcji. Według nich modelowanie jest trudne, ponieważ wymaga ono, uwzględnienia wielu czynników, takich, jak: okresów recesji i ekspansji, wysokiej i niskiej zmienności cen akcji. Obserwowana zmienność zwrotów lub cen na rynku akcji wynika z tego, że pożądane stopy zwrotów są już same wysoce zmienne, a dodatkowo są pchane przez cykliczne i inne krótkookresowe wahania w zagregowanym popycie. Zmienność ta ujawnia tendencje nielinearne w prognozowaniu na rynku akcji ${ }^{33}$. Jak można zauważyć w warunkach dużej zmienności cen papierów wartościowych, zarówno w krótkim okresie, jak i w dhugim okresie, okazują się bardzo pomocne analizy techniczne.

Analizę techniczną wykorzystują również X.Lin, Z.Yang, Y.Song, traktujący rynek akcji, jako kompleksowy i dynamiczny system, na którym podejmowanie decyzji jest utrudnione, $\mathrm{z}$ powodu szumu informacyjnego, a nawet chaosu informacyjnego, a dodatkowo niestacjonarnych szeregów czasowych. Ogólnie, na zmiany dokonujące się na rynku akcji wpływają złożone czynniki, które można podzielić na dwie grupy. Pierwsza $\mathrm{z}$ nich, stopniowa zmiana siły pomiędzy stroną kupujących a stroną sprzedających. Druga to czynniki związane z pewnym zakresem „błądzenia”, wynikającego $\mathrm{z}$ niespodziewanych zmian lub $\mathrm{z}$ codziennej zmienności dokonywanych operacji na giełdzie. W tej sytuacji, predykcja ceny akcji, może rzadko stanowić bezpośrednio wskazówkę dokonywania decyzji na giełdzie. Okazuje się, bowiem, że prognoza przyszłej ceny nie jest wystarczająca sugestią przeprowadzenia idealnej transakcji giełdowej, dającej najwyższy zysk. Idealną transakcję giełdową powinno przeprowadzić się, na szczycie lub w dołku trendu cenowego, tzn. dobry inwestor

${ }^{29}$ B.B. Mandelbrot, R.L.Hudson: The (Mis]behawior of Markets. A Fractual View of Risk, Ruin, and Reward, Basic Books. A Member of the Perseus Books Group, New York 2004, s. 82-85.

${ }^{30}$ T.Tyszka: Psychologia zachowań ekonomicznych, Wydawnictwo Naukowe PWN Sp. z o.o., Warszawa 1997, s. 89-106 i 160-178.

31 J.D. Schwager: Mistrzowie rynków finansowych. Rozmowy z najlepszymi amerykańskimi inwestorami i graczami giełdowymi, Wolters Kluwer Polska Sp. z o.o., Kraków 2007, s. 387-388.

${ }^{32}$ R. Curcio, Ch.Goodhart, D.Guillaume, R.Payne: Do Technical Trading Rules Generate Profits? Conclusions from the Intra-Day Foreign Exchange Market, Journal of Financial Economics, vol. 2, 1997, s. 267.

${ }^{33}$ G.S. Atsalakis, K.P. Valavanis: Surveying stock market forecasting techniques - Part II: Soft computing methods, Expert Systems with Applications, vol. 36, nr 3, Part II, April 2009, s. 5932. 
sprzeda akcje, gdy ich cena będzie blisko szczytu trendu, a kupi je, gdy zbliży się ona dna trendu. W związku, z tym, ważne jest przewidzieć nie tylko przyszłą cenę, ale również trend ceny, który osiagnie swój szczyt lub dołek ${ }^{34}$. Podobnie K.-Ch. Ko, S.J. Lin, H.J. Su, H.H. Chang wskazują na dużą przydatność analizy technicznej dla inwestowania w akcje i odbierania dzięki niej sygnałów z giełdy ${ }^{35}$.

Podobnie uważa J.H.Levin, że za pomocą analizy technicznej można identyfikować powtarzające się tendencje zmian badanych na rynku finansowym. Wydaje się, że większość reguł analizy technicznej pozwala ujawniać zachowania destabilizujące na rynku finansowym, chociaż nie ma jednoznacznego bezpośredniego dowodu empirycznego w tej kwestii. Jednakże, pośrednio analiza techniczna dostarcza dowodu empirycznego, choć nie jest on jednoznaczny. Bowiem, z jednej strony, inwestorzy w krótszych okresach, od tygodnia do miesiąca ekstrapolują niedawne tendencje. Wskutek tego analiza techniczna umożliwia im ujawnianie zachowań destabilizujących na rynku finansowym. Z drugiej strony, inwestorzy w dłuższych okresach, od kilku miesięcy i dłużej, prognozują przeciwstawne zachowania stabilizujące, prowadzące do równowagi $\mathrm{w}$ długim okresie na rynku finansowym ${ }^{36}$. Zatem pośrednio udowadnia się na podstawie analizy technicznej, że można ukazywać zarówno destabilizujące jak i stabilizujące zachowania na rynku finansowym, w zależności od przyjętego okresu analizy.

Ocenę wykorzystywania analizy technicznej bada się na podstawie ankiet przeprowadzanych wśród profesjonalistów rynku finansowego. St. Reitz uważa, że wprowadzenie analizy technicznej do modeli rynków finansowych można uzasadnić wynikami mikroanalizy z przeprowadzonych ankiet i uzyskiwaniem z nich korzyści na giełdzie ex post ${ }^{37}$.

Z wniosków Y.-H. Lui, D. Mole wynika, że ponad $85 \%$ ankietowanych uczestników rynku finansowego wykorzystuje zarówno analizę fundamentalną, jak $\mathrm{i}$ analizę techniczną $\mathrm{w}$ celu predykcji przyszłych zmian cen $\mathrm{w}$ różnych okresach. W krótszych okresach, dominuje skłonność do wykorzystywania analizy technicznej w przeciwieństwie do analizy fundamentalnej. Jednakże, skłonność ta stopniowo przeradza się $\mathrm{w}$ przeciwstawną, bowiem skłonność do wykorzystywania analizy technicznej narasta również, gdy wydłuża się okres predykcji. Analiza techniczna staje się nieznacznie bardziej użyteczna w prognozowaniu trendów, a szczególnie w predykcji punktów zwrotnych niż analiza fundamentalna ${ }^{38}$.

Interesujące badania ankietowe przeprowadził również L.Menkoff. Badania te przeprowadzono za pomocą ankiet wysłanych pocztą do profesjonalistów rynku finansowego w Niemczech. Służą one do ustalenia ważności analizy technicznej i jej zakresu wykorzystania na rynku finansowym. Przyjęto cztery hipotezy badawcze. Po pierwsze, analiza techniczna jest tylko zjawiskiem marginalnym na rynku. Pierwszej

\footnotetext{
${ }^{34}$ X.Lin, Z.Yang, Y.Song: Intelligent...op.cit., s. 11347.

${ }^{35}$ K.-Ch. Ko, S.-J. Lin, H.-J. Su, H.-H. Chang: Value investing and technical analysis in Taiwan stock market, Pacific-Basin Finance Journal, vol. 26, January 2014, s. 35.

${ }^{36}$ J.H.Levin, Chartist: Fundamentalists and Exchange Rate Dynamics, International Journal of Finance and Economics, vol. 2, nr 4, 1997, s. 281-282.

37 St. Reitz: On the predictive content of technical analysis, North American Journal of Economics and Finance, vol. 17, nr 2, 2006, s. 121-137.

${ }^{38}$ Y.H. Lui, D. Mole: The use of fundamental and technical analyses by foreign Exchange dealers: Hong Kong evidence, Journal of International Money and Finance, vol. 17, nr 3, June 1998, s. 535.
} 
hipotezy nie potwierdzono. Po drugie, oczekuje się, że analiza techniczna jest wtórną strategią i stąd powinna sama eliminować się. Niestety wykorzystanie analizy technicznej samo nie eliminuje się. Po trzecie, propozycja traktowania analizy technicznej, jako wtórnego źródła informacji, uzyskuje słabe wsparcie pośród profesjonalistów rynku finansowego. Faktycznie, analiza fundamentalna jest najważniejszym źródłem informacji w długim okresie. Po czwarte, traktowanie analizy technicznej, jako strategii samospełniającej się przepowiedni (zgodnie, z którą na ceny wpływają przede wszystkim czynniki psychologiczne), potwierdza się najsilniej.

Hipoteza rynku efektywnego nie może stanowić wyłącznej i pełnej podstawy badań empirycznych dotyczących rynku finansowego. Stąd potrzeba wykorzystywania analizy technicznej. Okazuje się ona, bowiem wykorzystywana do badania: opłacalności podejmowania decyzji, procesu formułowania oczekiwań opartych na zachowaniu nieracjonalnym czy też do anomalii rynku finansowego ${ }^{39}$.

W innym badaniu L. Menkhoff dochodzi do wniosku, że występuje powiązanie pomiędzy analizą techniczną a poglądem, że ceny są bardzo silnie zdeterminowane wpływami psychologicznymi. Stąd analitycy techniczni, uważają że trend kursu akcji na giełdzie jest wynikiem zachowania jej uczestników. W tym celu, przeprowadził on badania ankietowe pośród 692 menadżerów funduszy działających na 5 rynkach kapitałowych: Stanów Zjednoczonych, Niemiec, Szwajcarii, Włoch i Tajlandii. Dotyczyły one wykorzystywania analizy technicznej w podejmowaniu przez nich decyzji na rynku kapitałowym. Z tych badań wynika, że analiza techniczna stanowi bardzo ważne źródło informacji. Okazuje się, bowiem, że aż $87 \%$ z nich przyznaje jej ważność $\mathrm{w}$ podejmowaniu decyzji. Ponadto, w tym największa grupa menadżerów funduszy $(18 \%)$ preferuje analize techniczną przed innymi sposobami zdobywania informacji w procesie decyzyjnym ${ }^{40}$.

A.Shynkevich przypomina, że z dotychczasowych badań L.Menkoffa wynika, że użyteczność analizy technicznej jest najprawdopodobniej widoczna, gdy na ceny papierów wartościowych notowanych na rynku finansowym wpływają czynniki niefundamentalne. W tym przypadku, przyjmuje się zarazem, że na zachowanie inwestorów wpływają czynniki niefundamentalne, mające charakter systematyczny ${ }^{41}$.

Jak wynika z przeprowadzonego przeglądu wyników badań analizy technicznej okazuje się, że potwierdzają one tendencje mogące zajść w bliskiej przyszłości (do jednego tygodnia aż $\mathrm{w} 90 \% \mathrm{z}$ nich), opierając się na zachodzących zmianach z przyszłości na rynku finansowym. Dodatkowo, wnioski wyprowadzone na podstawie analizy technicznej w $60 \%$ są przynajmniej tak samo ważne, jak te wyciaggnięte w oparciu o analizę fundamentalną ${ }^{42}$.

\footnotetext{
${ }^{39}$ L. Menkoff: Examining the use of technical currency analysis, Journal of Financial Economics, vol. 2, 1997, s. 307-317.

${ }^{40}$ L. Menkhoff: The use of technical analysis by fund managers: International evidence, Journal of Banking and Finance, vol. 34, nr 11, 2010, s. 2573.

${ }^{41}$ A.Shynkevich: Performance of technical analysis in growth and small cap segments of the US equity market, Journal of Banking and Finance, vol. 36, nr 1, 2012, s. 193-208.

${ }^{42}$ Vigfusson R.: Switching ...op.cit., s.292
} 


\section{Wnioski}

W wyniku przeprowadzonego badania dokonano syntetycznego porównania analizy fundamentalnej i technicznej. Zaprezentowano najważniejsze wyróżniki analizy fundamentalnej i technicznej a na jego podstawie sformułowano końcowe wnioski (Tabela 1). Warto zaznaczyć, że pomiędzy badanymi sposobami analizy występują różnice. Jednakże, jak wynika ze sformułowanych wniosków w praktyce często one uzupełniają i wzbogacają się. Dają one pełniejszą wiedzę i informację o współczesnym rynku kapitałowym i jego uczestnikach, którzy nie zawsze są homo oeconomicus, kierującymi się przesłankami wyłącznie ekonomicznymi i finansowymi oraz działającymi zawsze racjonalnie. W podejmowaniu decyzji na rynku kapitałowym poszukuje się również rozwiązań średniookresowych, na co wskazują analitycy. Sformułowane wnioski wytyczaja pewne przesłanki do poszukiwania konsensusu pomiędzy nimi.

Współcześnie, w finansach behawioralnych, a konkretnie w modelowaniu zachowań inwestycyjnych uwzględnia się również czynniki psychologiczne. Jak można zauważyć uwzględniane czynniki w analizie technicznej nie umniejszają jej znaczenia w badaniu zmian cen papierów wartościowych na giełdzie, a nawet stanowią jej zalety w podejmowaniu decyzji inwestycyjnych.

Tabela 1. Porównanie analizy fundamentalnej i analizy technicznej

\begin{tabular}{|c|c|c|}
\hline Wyróżnik & Analiza fundamentalna & Analiza techniczna \\
\hline Poznawczy cel analizy & $\begin{array}{l}\text { Obliczenie wartości akcji na } \\
\text { podstawie danych ekonomicznych } \\
\text { i finansowych spółki }\end{array}$ & $\begin{array}{l}\text { Prognozowanie przyszłej zmiany cen } \\
\text { akcji za pomocą trendów jej cen } \\
\text { z przeszłości }\end{array}$ \\
\hline $\begin{array}{l}\text { Pragmatyczny cel } \\
\text { analizy }\end{array}$ & Inwestowanie na rynku kapitałowym & Granie na rynku kapitałowym \\
\hline Podmiot analizy & Inwestor & Gracz \\
\hline Przedmiot analizy & $\begin{array}{l}\text { Dane ze sprawozdań finansowych, } \\
\text { dane ekonomiczne i branżowe } \\
\text { i wartość akcji }\end{array}$ & $\begin{array}{l}\text { Cena rynkowa akcji, a nie wartość } \\
\text { akcji }\end{array}$ \\
\hline $\begin{array}{l}\text { Najczęstszy okres } \\
\text { analizy }\end{array}$ & Długi okres & Krótki okres \\
\hline $\begin{array}{l}\text { Założenie dotyczące } \\
\text { funkcji rynku } \\
\text { kapitałowego dla } \\
\text { inwestora/gracza }\end{array}$ & $\begin{array}{l}\text { Rynek koryguje cenę akcji w długim } \\
\text { okresie. } \\
\text { Inwestor powinien kierować się ceną } \\
\text { akcji w długim okresie, ponieważ } \\
\text { podlega ona korekcie na rynku w tym } \\
\text { okresie. }\end{array}$ & $\begin{array}{l}\text { Rynek dyskontuje wszystkie } \\
\text { informacje dla gracza w krótkim } \\
\text { okresie. }\end{array}$ \\
\hline Cel inwestora/gracza & Długookresowe zyski & Krótkookresowe zyski \\
\hline $\begin{array}{l}\text { Założony charakter } \\
\text { przesłanek } \\
\text { inwestora/gracza }\end{array}$ & Racjonalny & Nieracjonalny i racjonalny \\
\hline $\begin{array}{l}\text { Stosunek } \\
\text { inwestora/gracza do } \\
\text { ryzyka }\end{array}$ & Silniejsza awersja do ryzyka & Słabsza awersja do ryzyka \\
\hline $\begin{array}{l}\text { Czas podejmowania } \\
\text { decyzji }\end{array}$ & Na jak najdłuższy okres & Na jak najkrótszy okres \\
\hline $\begin{array}{l}\text { Podmiot wspierający } \\
\text { podejmującego decyzję }\end{array}$ & $\begin{array}{l}\text { Najważniejsza jest subiektywna } \\
\text { decyzja analityka, który uzasadniania } \\
\text { ją wybranymi zobiektywizowanymi } \\
\text { metodami i wskaźnikami }\end{array}$ & $\begin{array}{l}\text { Najważniejsze jest dla decydenta, co } \\
\text { wskaże rynek. Z samego pojęcia ceny } \\
\text { rynkowej akcji wynika bowiem, że } \\
\text { najważniejszy w określaniu jej ceny }\end{array}$ \\
\hline
\end{tabular}




\begin{tabular}{|c|c|c|}
\hline & & jest rynek. \\
\hline $\begin{array}{l}\text { Przesłanka wyboru akcji } \\
\text { do kupna }\end{array}$ & $\begin{array}{l}\text { W przypadku, gdy cena akcji spadnie } \\
\text { poniżej wewnętrznej wartości spółki, } \\
\text { ustalonej na podstawie sprawozdań } \\
\text { finansowych. }\end{array}$ & $\begin{array}{l}\text { W przypadku, gdy gracz ufa, że } \\
\text { sprzeda akcję za wyższą cenę } \\
\text { w krótkim okresie }\end{array}$ \\
\hline Użyteczność analizy & $\begin{array}{l}\text { Pomaga ustalić podwartościowe } \\
\text { i nadwartościowe akcje, aby podjać } \\
\text { korzystne decyzje przez inwestora }\end{array}$ & $\begin{array}{l}\text { Pozwala podjać korzystną decyzję } \\
\text { przez gracza, polegającą na określeniu } \\
\text { odpowiedniego czas kupienia lub } \\
\text { sprzedania akcji }\end{array}$ \\
\hline $\begin{array}{l}\text { Źródło gromadzonych } \\
\text { danych }\end{array}$ & Sprawozdania finansowe & Wykresy z trendami \\
\hline $\begin{array}{l}\text { Znaczenie przeszłości } \\
\text { i przyszłości w analizie }\end{array}$ & $\begin{array}{l}\text { Jednoczesne analizowanie danych } \\
\text { z przeszłości i ich prognozowanie dla } \\
\text { wyprowadzania wniosków dla } \\
\text { przyszłości }\end{array}$ & $\begin{array}{l}\text { Analizowanie trendów z przeszłości } \\
\text { na wykresach dla formułowania } \\
\text { wniosków na przyszłość }\end{array}$ \\
\hline $\begin{array}{l}\text { Wybrane } \\
\text { wykorzystywane } \\
\text { koncepcje }\end{array}$ & $\begin{array}{l}\text { Model wyceny przedsiębiorstw - } \\
\text { zdyskontowanych dywidend, } \\
\text { ROE (zwrot z kapitału), } \\
\text { ROA (zwrot z aktywów) }\end{array}$ & $\begin{array}{l}\text { Wykresy z trendami, indeks } \\
\text { relatywnej siły, średnia ruchoma } \\
\text { konwergencji dywergencji (MACD), } \\
\text { teoria Dowa, teoria fal Elliota }\end{array}$ \\
\hline $\begin{array}{l}\text { Stopień ważności } \\
\text { mierników i wskaźników }\end{array}$ & Pierwszorzędny & Drugorzędny \\
\hline
\end{tabular}

Źródło: opracowanie własne na podstawie wykorzystanej literatury.

Przegląd badań ankietowych uczestników giełdowych pokazuje jednoznacznie, że analiza techniczna jest przez nich w dużym stopniu wykorzystywana w podejmowaniu decyzji inwestycyjnych na giełdzie. Dominuje ona szczególnie w podejmowaniu tych decyzji w krótkim i średnim okresie oraz gdy nie wpływają czynniki niefundamentalne na ceny giełdowe. W tym przypadku, zachodzą pomiędzy nimi najsilniejsze sprzeczności.

Wyniki badań analizy technicznej i te oparte na hipotezie efektywnego rynku mogą również uzupełniać się wzajemnie, szczególnie w długim okresie, gdy coraz ważniejszy wpływ na ceny giełdowe mają czynniki fundamentalne. W analizie technicznej zakłada się, zarówno racjonalność, jak i nieracjonalność podejmowania decyzji przez inwestora. W hipotezie efektywnego rynku przyjmuje się, że inwestor postępuje racjonalnie. W praktyce, wyniki analizy fundamentalnej, opierającej się na hipotezie efektywnego rynku, i analizy technicznej uzupełniają i wzbogacają się.

\section{Literatura}

Achelis S.B.: Analiza techniczna od A do Z, Oficyna Wydawnicza LT\&P, Warszawa 1998.

Anghel G.D.I.: Stock market efficiency and the MACD. Evidence from countries around the world, Procedia Economics and Finance, vol. 32, 2015.

Atsalakis G.S., K.P. Valavanis: Surveying stock market forecasting techniques - Part II: Soft computing methods, Expert Systems with Applications, vol. 36, nr 3, Part II, 2009.

Bernstein P.L., A.Damodaran: Zarządzanie inwestycjami, Wydawnictwo K.E.Liber, Warszawa 1999.

Chen Ch.-W., Ch.-S.Huang, H.-W. Lai: The impact of date snooping on the testing of technical analysis: An empirical study of Asian stock markets, Journal of Asian Economics, vol. 20, nr 5, September 2009.

Curcio R., Ch.Goodhart, D.Guillaume, R.Payne: Do Technical Trading Rules Generate Profits? Conclusions form the Intra-Day Foreign Exchange Market, Journal of Financial Economics, vol. 2, 1997. 
Dusza M.: Rynek kapitałowy w Polsce. Narodziny, pierwsze dziesięciolecie, perspektywy, Biblioteka Menadżera i Bankowca, Warszawa 1999.

Fama E.F., M.E.Blume: Efficient capital markets: A review of the theory and empirical work, Journal of Finance, vol. 25, 1970.

Fang J., Y. Qin, B. Jacobsen: Technical market indicators: An overview, Journal of Behavioral and Experimental Finance, vol. 4, 2014.

Friesen G.C., Paul A. Weller, Lee M.Dunham: Price trends and patterns in technical analysis: A theoretical and empirical examination, Journal of Banking and Finance, vol. 33, nr 6, 2009.

Hagstrom R.G., Jr.: Na sposób Warrena Buffetta. Strategie największego w świecie inwestora kapitałowego, Wydawnictwo Naukowo-Techniczne, Warszawa 1996.

Hagstrom R.G.: Portfel Warrena Buffetta, Wydawnictwo Naukowo-Techniczne, Warszawa 2011.

Jóźwicki R.: Strategie Inwestycyjne, Wydawnictwo CeDeWu, Warszawa 2010.

Kacprzak D.: Czy ruchami cen na rynkach kapitałowych rządzi wyłącznie przypadek?, w: Rynek kapitałowy. Skuteczne inwestowanie, cz. 2, pod red. nauk. W.Tarczyński, Wydawnictwo Naukowe Uniwersytetu Szczecińskiego, Szczecin 2002.

Ko K.-Ch., S.-J. Lin, H.-J. Su, H.-H. Chang: Value investing and technical analysis in Taiwan stock market, Pacific-Basin Finance Journal, vol. 26, 2014.

Krawczak M., A.Jakubowski, P.Konieczny, R.Kulikowski, A.Miklewski, G.Szkatuła: Aktywne zarządzanie inwestycjami finansowymi. Zagadnienia wybrane, Akademicka Oficyna Wydawnicza EXIT, Warszawa 2003.

Kuang P., M.Schröder, Q.Wang: Illusory profitability of technical analysis in emerging foreign exchange markets, International Journal of Forecasting, vol. 30, nr 2, 2014

Levin J.H., Chartist: Fundamentalists and Exchange Rate Dynamics, International Journal of Finance and Economics, vol. 2, nr 4, 1997.

Lin X., Z.Yang, Y.Song: Intelligent stock trading system based on improved technical analysis and Echo State Network, Expert Systems with Applications, vol. 38, nr 9, 2011.

Lui Y.H., D. Mole: The use of fundamental and technical analyses by foreign Exchange dealers: Hong Kong evidence, Journal of International Money and Finance, vol. 17, nr 3, 1998.

Mandelbrot B.B., R.L.Hudson: The (Mis]behawior of Markets. A Fractual View of Risk, Ruin, and Reward, Basic Books. A Member of the Perseus Books Group, New York 2004.

Marshall B.R., M.R. Young, L.C. Rose: Candlestick technical trading strategies: Can they create value for investors? Journal of Banking and Finance, vol. 30, nr 8, August 2006.

Marshall B.R., R.H.Cahan: Is technical analysis profitable on a stock market which has characteristics that suggest it may be inefficient?, Research in International Business and Finance, vol. 19, nr 3, September 2005.

Menkhoff L.: The use of technical analysis by fund managers: International evidence, Journal of Banking and Finance, vol. 34, nr 11, 2010.

Menkoff L.: Examining the use of technical currency analysis, Journal of Financial Economics, vol. 2, 1997.

Murphy J.J.: Analiza techniczna rynków finansowych, Wydawnictwo Finansowe WIG-Press, Warszawa 1999.

Nawrocki T., B.Jabłoński: Inwestowanie na rynku akcji: jako ocenić potencjał rozwojowy spółek notowanych na GPW w Warszawie, Wydawnictwo CeDeWu, Warszawa 2011.

Piekunko I.: Zjawiska „gorączki złota” i „paniki” na Giełdzie Papierów Wartościowych w Warszawie, w: Rynek kapitałowy. Skuteczne inwestowanie, cz. 2, pod red. nauk. W.Tarczyński, Wydawnictwo Naukowe Uniwersytetu Szczecińskiego, Szczecin 2002.

Reitz St.: On the predictive content of technical analysis, North American Journal of Economics and Finance, vol. 17, nr 2, 2006.

Schwager J.D.: Mistrzowie rynków finansowych. Rozmowy $\mathrm{z}$ najlepszymi amerykańskimi inwestorami i graczami giełdowymi, Wolters Kluwer Polska Sp. z o.o., Kraków 2007. 
Shynkevich A.: Performance of technical analysis in growth and small cap segments of the US equity market, Journal of Banking and Finance, vol. 36, nr 1, 2012.

Sopoćko A.: Giełda papierów wartościowych, PWE, Warszawa 1991.

Spólnik G.: Efekt stycznia czyli o rynkowych anomaliach, Miesięcznik Kapitałowy, styczeń 2010.

Szyszka A.: Finanse behawioralne. Nowe podejście do inwestowania na rynku kapitałowym, Wydawnictwo Uniwersytetu Ekonomicznego w Poznaniu, Poznań 2009.

Tabęcka M.: Nowoczesne i behawioralne podejście do teorii finansów oraz budowy portfela, w: Strategia zarządzania portfelem inwestycyjnym, pod red. nauk. J. Kotyński, LAM-Wydawnictwo AKADEMII FINANSÓW, Warszawa 2010.

Tarczyński W.: Rynki kapitałowe. Metody ilościowe, vol. 1, Agencja Wydawnicza PLACET, Warszawa 1997.

Tarczyński W.: Wykorzystanie sztucznych sieci neuronowych na rynku kapitałowym, w: Rynek kapitałowy. Skuteczne inwestowanie, cz. 1, pod red. nauk. W.Tarczyński, Wydawnictwo Naukowe Uniwersytetu Szczecińskiego, Szczecin 2002.

Taylor M.P.: Editor's Introduction, International Journal of Finance and Economics, vol. 2, nr 4, 1997. Tyszka T.: Psychologia zachowań ekonomicznych, Wydawnictwo Naukowe PWN, Warszawa 1997.

Vigfusson R.: Switching Between Chartists and Fundamentalists: A Markov Regime-Switching Approach, International Journal of Finance and Economics, vol. 2, nr 4, 1997.

Zielonka P.: Czym są finanse behawioralne, czyli krótkie wprowadzenie do psychologii rynków finansowych, Materiały i Studia, z. 158, NBP, Warszawa 2003.

Zielonka P.: Technical analysis as the representation of typical cognitive biases, International Review of Financial Analysis, vol. 13, nr 2, Summer 2004.

\section{Summary}

The aim of the paper is a comparison of the assumptions of the efficient market hypothesis with the technical analysis effects. The research problem is a contradictory or complementary nature of the efficient market hypothesis with the technical analysis. The efficient market hypothesis is based on the investor rationality assumption and the technical analysis is taking into account of investor rationality and its irrationalities. Therefore, we show the concept of technical analysis and its assumptions. Then, we assess the efficient market hypothesis in the context the technical analysis. In the latter part of this paper we show the usefulness of the technical analysis for the financial market and its assessment is presented by the financial market participants. Conclusions of the research are presented in the last part of this article.

Key words: The Efficient Market Hypothesis, technical analysis, financial market, stock exchange, rationality

\section{Informacja o autorach:}

\section{Dr Grzegorz Paluszak}

Uniwersytet Warszawski, Katedra Bankowości, Finansów i Rachunkowości, ul. Długa $44 / 50$

00-241 Warszawa

gpaluszak@wne.uw.edu.pl

Dr Joanna Wiśniewska-Paluszak,

Uniwersytet Przyrodniczy w Poznaniu, Katedra Ekonomii,

ul. Wojska Polskiego 28

60-637 Poznań

wisniew@up.poznan.pl 